\title{
Eurasian Economic Union's Effect on Global Politics and the World Economic System
}

\author{
Aşkın İnci Sökmen \\ İstanbul Arel University, İstanbul, Turkey
}

\begin{abstract}
The new Eurasian Economic Union (EEU) has now become a reality coming into effect today allowing free movement of trade, services and capital. Its treaty was signed on 29 May 2014 by the leaders of Belarus, Kazakhstan and Russia. EEU has an integrated single market of 176 million people and a gross domestic product (GDP) of over four trillion US Dollars. From the point view of Nye and Keohane's interdepence theory, this trade block formed under Moscow's leadership also begs the question, if the Soviet Union will also reunite and be re-established. Russia seems to look at it not just in economic terms, but as a way to expand Russian influence in the region. The biggest criticism of the union seems to be re-establishment of the crumbled Soviet Union. On the other hand Russia has wanted to launch talks with the newly born EEU despite the Ukraine Crisis. German Chancellor Angele Merkel has supported to establish a common economic space in the Eurasian Region including the focus countries of Eastern Partnership (an EU policy on closer ties with Armenia, Azerbaijan, Belarus, Georgia, Moldova and Ukraine). A new Russia-led blocs as a better partner for the EU than the US could cause to deemphasize new Trans-Atlantic Treaty. Another point, the union is actively seeking to increase trade with East Asia. It commenced talks for official trade cooperation with Association of Southeast Asian Nations (ASEAN). Therefore we can say that EEU includes strategic interests as well as economic interests for its members, especially for Russia. In order to link both Europe and East Asia, Russia seeks to develop its eastern regions to increase its access to Asian markets. Far East markets have become so important for Russia since the European Union and the United States imposed sanctions on Russia following crisis in Ukraine. In this article my aim is to analyze EEU effects on global politics and the World Economic System.
\end{abstract}

Keywords: Russia, Eurasian Economic Union, geopolitics and geo-economy of Eurasia, new power economical balance in global competition

\section{Introduction}

Towards the end of the 20th century, many trials of economic union and territorialization emerged among the countries as alternatives to rapid globalization, which appeared economically across the world. Economic unions such as the European Union (EU) and European Free Trade Association (EFTA) that achieved a significant success brought important defiance cases with them within the economic and political orders, which were created after the Second World War and rules of which were set by the USA. Regional organizations, which were parallel to these economic unions, started to be established to shape the structure that appeared with the dispersion of the Soviet Union in Eurasia. One of them, which stands out in the global and regional sense, is 
the Eurasia Economic Union (EEU) aiming at becoming a supranational union similar to the European Union together with the participation of five countries within the Northern Eurasia; it came into effect as of January 1, 2015 and its membership is based on the volunteering and equality principle.

The project of the Eurasia Economic Union that had the purpose of creating a common market and a common economic policy in the member countries was firstly suggested by the State President of Kazakhstan Nursultan Nazarbayev in Moscow State University on March 29, 1994. The project, for which the support of Russia took time, gained importance with the President Putin in 2000. In an article in Izvestia in October 2011, the President Putin proposed forming a Eurasian Union. Except for the Baltic States, the former Soviet Republics was aiming at a union in a common economic area (Putin, 2011). The 20-year foundation period primarily began with the Customs Union Treaty signed between Russia and Belarus in 1995. Besides these two states, Eurasian Economic Community (EurAsEC) appeared together with the participation of Kazakhstan, Kyrgyzstan and Tajikistan in 2000. The only economic area where goods, services, capital and labor force were included in the free circulation was formed among the member states. After the Customs Union Treaty that enabled the intensive economic integration among them in 2010, Russia, Belarus and Kazakhstan signed the treaty on the foundation of the Eurasian Economic Union on May, 29 2014. The treaty came into force on January 1, 2015. Treaties aiming for Armenia's and Kyrgyzstan's accession to the Eurasian Economic Union were signed on 9 October 2014 and 23 December 2014, respectively. Only Kyrgyzstan's accession treaty will not come into force until it has been ratified. Here, the important point is the fact that the countries which constitute the EEU take a fourth institutional step after the Single Economic Space, Customs Union and Eurasian Economic Community. EEU is a union of states acting on the basis of the principles of equality, non-interference in the internal affairs of its members, respect for sovereignty and the inviolability of national borders (Eurasian Economic Commission, 2013, p. 18).

The Eurasian Union is significant in terms of the foundation of the Eurasian Economic Union and its actualization in a chaotic period when the intense global competition was experienced between the USA, Russia and China and the Ukraine crisis and the Western sanctions tried the economic and political isolation of the Russian federation. It can change the power balances between great states in respect of the results and helps Russia to enable its economic security and take the regional influence areas under its own control by returning to the world politics as a great power again rather than its isolation. It will also enable the member countries to be efficient primarily in the energy sector (natural gas and oil) and the global economy as a bloc within the union. It aims at becoming one of the important economic potential centers, which functions as a bridge between Europe and the dynamic Asia-Pacific region. Being an independent center of global development is also aimed without becoming a periphery of Europe or Asia. It provides the member countries of the union with the equal partner opportunity in the negotiations with the other regional establishments such as EU, North American Free Trade Agreement (NAFTA), Asia Pacific Economic Cooperation (APEC) and Association of Southeast Asian Nations (ASEAN) (Putin, 2011).

They try to have a word in the global governance by presenting new establishments within the global system of an eastern world under the leadership of China and Russia as an alternative to the Western world under the leadership of the USA. The search for a multipolar system in the world order of the 21 st century in terms of Russia is based on the consideration of the gathering of the power in a certain group or center internationally as a threat. The disturbance of China against the hegemony of the USA allowed both states to act commonly in economic, military and political issues. Economic territorialization formations, which emerge 
in the "Near Abroad" expressing the lands of the former Soviet Union as the primary benefit area for Russia, is significant for constituting a great power balance against the hegemony of the USA. In this sense, the fact that the USA is not a dominant power in various regions of the world and Russia and China expand their zone of influence for the benefit of America has a strategic attempt. This article examines the Eurasian Economic Union from the geopolitical and geo-economic perspectives and the role of the Western bloc under the leadership of the USA, China and Russia within the new economic order which they want to form as revisionist powers.

\section{A Region Which is Geo-strategically and Geo-economically Significant: Eurasia}

Eurasia is the name given to the geographical region covering the European (Euro) peninsula and Asia. It is comprised of the combination of the words Europe (Eur) and Asia (Originally, "Eurasia" is a geographical notion in this sense, it is simply the biggest continent as referring the combined landmass of Europe and Asia. However geopolitically, Eurasia notion has several different meanings, reflecting the specific geopolitical interests of each notion). Despite the presence of many countries in the region, Russia takes part in the political analyses in terms of its policies. Strategically, the Eurasian region expresses a large continental area associated with the Russian Federation. From the perspective of European strategist, Russia (including Ukraine) should be integrated into Europe economically, politically and even militarily in respect of Eurasia concept. On the other hand, the Russian concept of the geopolitical Eurasia is very different from the European one, to the land area of Imperial Russia in 1914, including parts of Eastern Europe (Nartov, N. \& Nartov, V., 2007, p. 50). The Russian Federation view today is that "Eurasia" consists of the land lying between Europe and Asia which made up of Western and Central Russia, Belarus, Ukraine, part of Caucasus, Uzbekistan, Kazakhstan, Tajikistan and Kyrgyzstan.

In terms of the Western Atlantic group, the significance of Eurasia is its indication as the primary target in the geopolitical theories written to determine the world domination. Halford Mackinder based the development of the political history upon the geopolitical basis in his article The Geographical Pivot of History published in 1904 and separated the world geography into the pivot area-Heartland, inner crescent and outer crescent. He included Germany, Austria, Turkey, India and China in the inner crescent, and England, Southern Africa, Australia, USA, Canada and Japan in the outer crescent. Mackinder names the northern and central land of the Eurasian region where Russia is located as "Geographical Axis of the History". The (hold the key to the world domination) Heartland Theory, which he presented for the world domination, directed the policies of the states to become a super power. According to Mackinder (1904), the Eurasian domination was necessary for the World domination. American President Carter's national security adviser Zbigniew Brzezinski, who revised the studies of Mackinder stated in his book, Game Plan: A Geostrategic Framework for The Conduct of The US-Soviet Contest, "Whoever controls Eurasia dominates the globe. If the Soviet Union captures the peripheries of this landmass... it would not only win control of vast human, economic and military resources, but also gain access to the geostrategic approaches to the Western Hemisphere-the Atlantic and The Pacific..." (Brzezinski, 1986, pp. 22-23). The most important state that could hinder the zone of influence in the Eurasian region, which would help England and America to be active in world policies, was the Russian Federation.

Today, opposition of anti-American hegemony requires Eurasia to have its own control in line with the multipolar world and power centers policy followed by the Russian foreign policy. In the formation of the 
Russian foreign policy, groups that call themselves Atlanticist, Eurasianist and Centralist are active (Malcolm, Pravda, Allison, \& Light, 1996, pp. 34-35). According to the most important ideologist of the Russian Eurasianists Alexander Dugin, Russia must be identified with its own Eurasian identity, neither Europe nor Asia. They consider its defiance of Eastern and Western cultures and protection of its own identity as a historical obligation for the continuity of the Russian independence. They argue that it is possible for Russia to be a super power again only with the Western and especially American opposition. Continental geopolitical powers, which make use of political, military, strategic and geopolitical sovereignty, must be active against the single world domination (American domination). The Eurasian geography is of vital significance for the Russian Federation to become a continental geopolitical power (Dugin, 2003, p. 11). As a union, the integration of Eurasia will enable the states which are voluntary for joining the integration in that region to be sovereign and independent against the Atlantic alliance.

However, the obstacle in front of Russia to become the single active power in Eurasia is the Public Republic of China which is expanding its zone of influence rapidly and in competition about Russia and the Central Asia in a sense, rather than the Western bloc. For China to become stronger against the USA, Russia turns this competition into collaboration and enables it to be more active in the region. With the dispersion of the Soviet Union in 1991, increasing the influence and building power upon the independent states that appear in the Central Asia and Caucasia led to a competition among the European Union, USA, China, India, Turkey and Iran. China was at the forefront compared to the other countries and substantially increased its effect in the region with the projects it developed. The fact that the countries of the Central Asia consisting of Kazakhstan, Kyrgyzstan, Tajikistan, Turkmenistan and Uzbekistan, which were included in the former Soviet Union, were landlocked countries without any access to the seas had an effect on it (Pomfret, 1995, p. 39). It tries to actualize the New Silk Road project overland by establishing railway networks in the region. It simplifies the integration of these countries into the world economy with the railway network. Thanks to the high-speed railway, China connects the other places of the world, Europe, Middle East, Southeastern and southern Asia. China obviously aims to be the designer and the principal hub of an emerging Eurasian connectivity web. Connection of the Eurasian Economic Union with the Economic Silk Road network was accepted between Moscow and Beijing. Greater Eurasia which emerges as a result will become a significant economic attraction area. It can be asserted that China, ranking as the second country in the world economy, has surpassed the USA and follows a policy which complies with Mackinder's theory. It is claimed that China is founding the 3rd Eurasian Empire with its striking leadership in Eurasia (Lukin, 2015).

Eurasia is also significant for having oil, natural gas, coal and uranium energy resources besides being a geopolitical key area for the world domination. According to 2015 proved crude oil reserves in Eurasia, the capacity is 119 billion barrels in total. Eighty billion barrels belong to the Russian Federation and 30 billion barrels to Kazakhstan. The remaining amounts are constituted by Azerbaijan (7 billion), Turkmenistan (0.6 billion), Uzbekistan (0.594 billion), Ukraine (0.395 billion), Kyrgyzstan (0.04 trillion), Georgia (0.035 trillion) and Tajikistan (0.012 trillion). In respect of natural gas, 2015 proved crude reserves in Eurasia are 2178 trillion cubic feet in total. 1688 trillion cubic feet of this amount belongs to Russia which ranks at the top in the natural gas production across the world. Then, Turkmenistan (265 trillion c feet), Kazakhstan ( 85 trillion), Uzbekistan (65 trillion), Ukraine (39 trillion), Azerbaijan (35 trillion c feet), Georgia (0.3 trillion), Kyrgyzstan and Tajikistan (0.2 trillion) follow it (EIA, 2015). Undiscovered oil and natural gas reserves which it has especially by the Caspian Sea have boosted the interest in the region. Western experts believe that the largely untapped oil 
and natural gas riches of the Caspian Sea countries could make that region the Persian Gulf of the next century.

Great Game, the struggle between the Russia and England in the Central Asia of the 19th century, which the British Author Rudyard Kipling mentioned in his novel Kim (1901), came to life again on the lands of the Former Soviet Union named by Russia as the Near Abroad. This new Great Game is a contest among Russia, USA and China for power and influence in Central Asia. With the end of the Soviet involvement in the region and the end of Cold War, the expression The New Great Game was used to describe renewed geopolitical interest in Eurasia region, especially Central Asia, Caspian Region and Trans-Caucasus based on the mineral wealth of the region which was becoming available to foreign interests. Signing treaties on pipelines, tanker routes and oil consortia, having military bases, establishing economic and security organizations became the means of being effective on these countries among the rival states. Having military bases in order to make use of the energy resources of the region for China and the USA and help struggling with the Al Qaeda terror organization in Afghanistan for the USA is important in the New Great Game in terms of obtaining a strategic advantage in the region. Kyrgyzstan was the country which hosted both a US base and a Russian base in its lands simultaneously in the world. Whereas the Man as military base owned by the USA was decommissioned in 2009, The Kant Air Base of Russia continues its activities with the serious economic help of Russia for Kyrgyzstan.

It is still a significant tactic of the struggle between the USA and Russia to attract the regimes of the countries in the Central Asia to their own side, convince, put pressure and make governmental changes with color revolutions (Orange Revolution in Ukraine and Rose revolution in Georgia) aiming at democracy. From the point of Russia, color revolutions have been a new form of warfare invented by western governments seeking to remove independently minded national governments in favor of the ones controlled by the West. As a counter strategy, Russia tries to build political alliance relationship with the authoritarian regimes in the target and to damage the western alliance unity in the military sense (Gorenberg, 2014). Shanghai Cooperation Organization led by China, Collective Security Treaty Organization led by Russia and Eurasian Economic Union led by Kazakhstan, which were founded in the region, must be evaluated as an alliance strategy against the possible color revolutions. The countries of especially the Central Asia must strengthen themselves economically and create job opportunities for their own publics for the riots which may occur in case of socio-economic problems of the public. For the economies with deprivation of access to the seas, undeveloped transportation infrastructure and raw material based export structures, the collaboration organizations for which membership is obtained increase the economic self-sufficiency and help with being active in the world economy as a bloc. Although a multidirectional collaboration relationship was adopted with the West, China and Russia based regional establishments outweighed. It can be claimed that the incidents that have occurred in the region since 1991 have an effect on this preference. While the EU membership lost its charm due to the status of American-supported Georgia in 2008, economic problems of the EU after the global economic crisis in 2008, the status of especially Greece, Spain and Portugal and suppression of the economic and political sovereignty of Greece for the debt discharging, the Ukraine crisis which began in 2013 led to the establishment of a relationship at arm's length with regard to the USA and EU. About the protection of the political sovereignty, equal membership and non-interference with internal affairs, China-led Shanghai Cooperation Organization and the Eurasian Economic Union have become the primary priority for the member states.

The spying scandal related to the German government in the original documents of Edward Snowden in Russia, the USA National Security Agency (NSA) former system analyst of the German Journal Der Spiegel 
(from the archive of former NSA contractor), can be given as an example for the damaged union of the Western alliance. The information stating that German Chancellor Angela Merkel's cell phone was surveiled by the NSA and the American embassy in Berlin was used as a surveillance station with the purpose of intelligence was included in the documents. The US diplomatic mission in Germany has not merely been promoting German-American friendship. These spying have posed a threat to German-American relations in the sense of alliance trust. Even the NSA spying scandal lead to questioning the Trans-Atlantic free trade agreement and partnership (Spiegel, 2013).

In the matter of the New Great Game which especially continues in Eurasia, especially Central Asia and Caucasia, the Russian leader Putin stressed again "Eurasian space is not a chess board or a field for geopolitical games. This is our home and we want peace and prosperity to reign in our home" in his last speech at the Seventh BRICS Summit held on June 9-10, 2015 in Ufa. Joint work within the framework of alliances and organizations like BRICS (a group acronym that refers to the countries of Brazil, Russia, India, China and South Africa), Shanghai Corporation Organization (SCO) and the Eurasian Economic Union can ensure reliable conditions for sustainable growth (President of Russia, 2015). Russia which sees Eurasia as its own survival area and China that increases its effectiveness with the Shanghai Cooperation Organization and the New Silk Road project have gained a central position through their organizations established for the other countries in the region within the framework of a zero-sum strategy against the EU and especially the USA. The strategic partnership established between Russia and China is considered as a counter attack against the expansionism of the Western alliance.

\section{Significance of the Union in Terms of Member States}

Eurasian Economic Union is an international organization for regional economic integration consisting of Kazakhstan, Russia, Belarus, Armenia and Kyrgyzstan. It has international legal personality and is the established by the Treaty on the Eurasian Economic Union. Although it's a union founded considering the EU treaty as an example, political integration isn't among its goals. It is set to become a reality on the basis of the Customs Union and the common economic sphere. The treaty that founded the union was prepared according to the rules of the World Trade Organization. According to the Union Treaty, free movement of goods, services, capital and labor would be provided to pursue a coordinated energy policy and form common energy markets (electric energy, gas, oil and oil products) based on common principles. They have planned formation of single market of electric power which is planned to be completed by 2019, and single market of hydrocarbons by 2025. Moreover, by January 1, 2016, single market of pharmaceuticals and single market of medical devices (devices for medical purposes and medical equipment) will be created within the Union. The parties agreed on a step-by-step liberalization of transport carriages in the territory of the will-be Union, which pertains primarily to motor and railroad transport. An agreement has been reached on the formation and implementation of a coordinated agricultural policy.

In a period which experiences a general slowdown in the global economy, it is one of the most significant goals to become one of the greatest commercial blocs of the world such as EU, NAFTA and ASEAN. For example, creation of the ASEAN resulted in the fact that the region occupied the first place in the World in rates of economic growth. Economic integration seems as an obligation for the economies of the developing countries in the region. After the dispersion of the Union of Soviet Socialist Republics (USSR), the former Soviet countries within the union couldn't assure full-stability economically. The reason resulted from the fact 
that the Soviet economy was established on self-sufficiency and regional specialization. These countries were raw material producers and suppliers and their industrial and service sectors couldn't be developed fully. Because the commercial volumes decreased after the independence, growth rates moved negatively. They achieved regional economic integrations such as the Commonwealth of Independent States and Central Asian Cooperation, because they wouldn't be able to maintain their economic independences on their own (Stroev, Bliakhman, \& Krotov, 1999, pp. 407-411). Eurasian Economic Union is considered as a more active union because of the Central Asian Cooperation which combined with the Eurasian Economic Community and the Commonwealth of Independent States that achieved no full integration.

Within the Eurasian Economy Union, countries that depend on Russia are Belarus, Kyrgyzstan and Armenia. Belarus is the most vital strategic partner of Russia in security, energy, economic and socio-cultural terms. Because Kyrgyzstan is a country which has no energy resources, a quite weak economy, relies on foreign assistance and feels isolated internationally, membership for this union is seen obligatory. Criticisms claiming that the gold mining in the country would be damaged after becoming a member of the union weren't taken into account so much, because the inflow of receipts sent by the Kyrgyz workers who go to Russia provide serious contribution to the economy and guaranteeing the worker migration to Russia within the framework of the Union treaty is at issue. The Russian Natural Gas company Gazprom purchased the state company Kyrgzgaz of Kyrgyzstan in return for the materialization of the energy infrastructure investments of the country. And Armenia is a country which has no other choice other than Russia in respect of security, economy and domestic policy. Collective Security Treaty Organization, which doesn't include Azerbaijan as a member, is of great importance due to the problem of Mountainous Karabakh. The Russian military base in Gyumri, the Armenian-Russian associated company, which manages the natural gas trade of Gazprom and Armenia, the $80 \%$ share in Arm Rosgazprom and the inflow of receipts sent from Russia to Armenia simply enable the stability of the regime under the governance of Robert Kocharyan in Armenia. Kazakhstan is a country which could succeed in developing a stable relationship with both Russia and the West. With rich energy resources, it has become the greatest economic power of the Central Asia by completing all the legal arrangements required for the market economy. Its banking system is in a better situation than Russia. It has become an indispensable country for Russia due to its political potential. It plays a key role between the European Union and Russia. Kazakhstan is one of the countries where workers from the Central Asia such as Russia come for work. Economic stability of each country is affected depending on the fluctuations in the oil market.

It wasn't possible to cover up the economic failure, which led to the dispersion of the USSR in 1991, with the neoliberal economic policies followed in the Russian Federation during the presidency of Boris Yeltsin. Washington Consensus that forms the road map of the neoliberal globalization, privatization of state institutions, World Bank and IMF, weakening of the distribution channel of the state, opening the economy to foreign investors and the prescriptions including the right of acquisition of private property made the Russian economy as the "shock therapy" hit bottom with the Asian crisis of 1998 (Murrel, 1993, pp. 122-123). In Latin America, South Africa and Russia, Washington based development policies caused the community overall to become impoverished and crises occurred leading to social explosion. "Beijing Consensus", an alternative to the Washington Consensus that played a significant role in the economic development of China, was based on the decisiveness of the state in economy ( $\mathrm{Li}, 2009$ ). Vladimir Putin, who came to power in 2000, adopted the economic development model followed by China and restructured the Russian economy under the leadership of 
the state.

Besides the reinforcement of the central state in the Russian politics together with the economy, the Siloviki group consisting of army, police, intelligence service and jurisdiction members appeared with the President Putin as managerial elites. These political elites who adopted the Western opposition see the USA and the economic and military organizations under their leadership as the external threats that aim at disappearance of Russia. They strategically adopted the requirement of re-establishing a powerful organization in the Former Soviet lands of Russia referred as "Near Abroad" (Renz, 2006, p. 903; Bremmer \& Charap, 2007). Whereas these viewpoints that consider the whole Former Soviet Geography as the survival benefit area of Russia in terms of security and economy in Karaganov Doctrine (1993), they were applied through the establishment of close relationships with the Commonwealth of Independent States (CIS) countries during Yevgeni Primakov's Ministry of External Affairs (1996-1998). The last accessed point of this strategy, which continues during the period of the President Putin, the entry of the Eurasian Economic Union into force.

The main domino power of the recovery and stability of the Russian economy is the income obtained from the energy that increases its self-confidence. Energy companies have become key sectors during the restructuring period in economy. Usage of the natural resources for the economic development was based on the thesis "planning of the regional resources in the formation of the market economy", which was written academically by the President Putin (Balzer, 2006, pp. 48-54). While Russia ranks within the global economic system as a G8 country and member of the World Trade Organization with its energy resources, this led to the strengthening of the national oil and natural gas companies (NOCs) checked directly by the state in the energy market and its domination in the area. International companies (IOCs) based on the US and European capitals started to recede against the NOCs of Russia, China, Venezuela, Iran, Brazil and Malaysia that control $77 \%$ of the reserves across the world (Jaffe, 2007, p. 8). The new oil and natural gas seven sisters in the energy market were constituted by Saudi Aramco, Russia's Gasprom, China National Petroleum Corporation (CNPC) of China, National Iranian Oil Company (NIOC) of Iran, Venezuela's PDVSA, Brazil's Petrobras and Petronas of Malaysia. They have consolidated their power as aggressive resource holder and rule makers on the control of the industry and the market and pushed the world's biggest listed energy groups, which emerged out of the original seven sisters (Exxon Mobil and Chevron of the US and Europe' BP and Royal Dutch Shell Petrol.) From BRICS countries, Russia Gasprom and Petro China and Petrobras of Brazil have outshone Exxon Mobil, BP and Shell in share price gains (Hoyos, 2007). Russia Gasprom (The Russian Federation controls a 50.23\% stake in the share capital of Gasprom), which is the biggest natural gas company of the world-The company owns the world's largest gas transmission network - achieves the geostrategic goals of the Russian foreign policy with the energy pipelines it built and enables Russia to increase its effect in the international area by establishing partnerships with the state companies of the other countries in the world and participating in projects. Whereas Europe, CIS and Baltic countries constituted its most basic market, it began to increase its effectiveness in the Asia-Pacific and North America energy markets by entering the liquefied natural gas (LNG) market. Single markets of hydrocarbons, which the Eurasian Economic Union wants to surpass within ten years, will help it to obtain significant power against the countries outside the union in terms of the prices of these resources. In case of the participation of Tajikistan, Turkmenistan, Uzbekistan and Azerbaijan in the union as new members, the union will become a key organization against the foreign investors in terms of the control, supply and prices of the energy reserves in the Eurasian region. For Russia, it will have increased its effect on controlling and directing the production and export of oil and natural gas of the other members within the union. 
It can be claimed that especially the goal of Gasprom to establish itself as a leader among global energy companies by diversifying sales markets and ensuring reliable supplies will have come true. The New Great Game based on the control of the energy resources will have ended up for the benefit of Russia. That would leave the USA as a non-hegemonic country and Russia would have strong power over Pipelineistan.

The Ukraine crisis and Crimea developments keep the Russian economy under a serious threat. The decrease in the oil prices depending on the economic embargo imposed by the USA and EU, production surplus due to Saudi Arabia and poor demand led to a fall in the incomes of the Russian economy and value loss of the Russian Ruble. Oil prices decrease because Saudi Arabia continues production without any cut and Iraq, which has the second biggest reserve, increase its production and export. Due to the falling prices, Russia has to produce more oil to cover its export deficit. The price decreases in oil have separate importance in respect of the economic security of Russia. Right after the occupation of Afghanistan by the USSR in 1979, Saudi Arabia's sudden and radical reduction in oil prices caused economic rout in the Soviet Union. A similar situation was observed after the connection of Crimea to the Russian Federation: The Saudi Arabia-induced decrease in the oil barrel prices indicated the new king's support for the financial /economic war on Russia. The oil price shock leads to damage not only on Russia but also Iran and Venezuela. This was named as an "Empire of Chaos" power game on which Russia agreed for Saudi Arabia and the USA (Escobar, 2014; RT, 2015). In relation to enabling the price stability, Russia has oriented to energy trade with other money currencies apart from dollar to break the hegemony of the American dollar, especially petrodollar in the global financial system together with China. It is observed in both countries that they see the EU as a model and give great significance to transmission to EURO, the only monetary system bringing the hegemony of the American dollar to an end. In 2002, the former Iraqi leader Saddam Hussein transited from petrodollar to euro for Iraq's purchase and sale of oil for a short time. In face of sanctions on Russia, Gasprom decided on paying certain customers over Euro instead of the US dollar. Efforts to establish Yuan-ruble oil and natural gas purchase-sale system, the common exchange reserve, which was studied in the last Ufa meeting of the BRICS on June 9-10, 2015, (Petro China and Petrobras of Brazil, from new energy sisters, using a different money currency except for the dollar) and a common currency of the Eurasian Economic Union decided to be the altyn which is to be introduced by 2025 are important developments for the Russian economy. Hegemony of petrodollar was provided with pricing the oil export over dollar and investing the foreign trade surplus obtained from the oil trade in the USA debt instruments within the framework of the agreement signed between the USA and Saudi Arabia in 1973 and attended by the OPEC members. It will also have an effect on the elimination of a single Market with hydrocarbons and the hegemony of petrodollar, the altyn single currency, within the Eurasian Economic Union. Orientation of national oil and natural gas companies, which control $77 \%$ of the world energy system, to another currency other than dollar will enable the economic was against Russia to turn out to its own advantage. Thus, Russia both guarantees its own economic security by supporting the use of different currencies in the global trade and weakens the American domination in the world economy by creating currency wars.

A very significant factor that may affect the decrease in the oil barrel prices is the disembargo on Iran limited to one million barrels of oil production within the framework of the nuclear agreement concluded with Iran. Iran, which will try to take the market share back from Saudi Arabia targets producing five million barrels per day until 2020. It may cause the economic war planned by the Saudis to turn out to their own advantage. Nuclear agreement of Iran approved by the USA is evaluated as a serious breaking point in terms of the USA-Saudi Arabia relationships. In the economy forum in St. Petersburg on June 18, 2015, Saudi Deputy 
Crown Prince Mohammed Bin Salman bin Abdulaziz, who stressed the importance of the position of Russia in the international community and the UN Security Council for the provision of security and stability, signed the military and nuclear cooperation agreement with Russia. Two biggest producers of oil in the World are on the way of cooperation (Agnihotri, 2015). Russia seems to have turned the slowdown in the relationships between the USA and Saudi Arabia into an opportunity. Because of Iran, Saudi Arabia may not continue its low oil barrel price policy longer.

In the Shanghai Cooperation Organization (SCO) where Iran has an observer status, its transition to full membership after India and Pakistan will be a crucial development in respect of the world economic balances. With respect to energy, Iran can be considered a regional rival for Russia, too (Francis, 2015). However, Russia continued its economic and political cooperation with Iran during the sanctions. Decision was made on forming a common bank or account to regulate the mutual payments in commercial relationships. Iran has a crucial energy node of West Asia. About natural gas, the Iranian leader's Ali Hamaney's suggestion of establishing a monopoly — similar to the Organization of Petroleum Exporting Countries (OPEC)—on natural gas production and prices (Gas Troika or Gas Cartel) where Russia and Qatar are also included, in 2007 can have significance for Russia in this period (Pannier, 2008). Within the scope of a Russia-Iran and Eurasian Economic Union acting collaboratively against the countries that want to diversify the natural gas energy suppliers except for Russia both in Europe and Balkans with the Ukraine crisis Russia and Central Asian/Caspian countries (with the participation of new members) will make the realization of this thought impossible.

Russia which wants to overcome the problem of Ukraine and restrict the movement area of the NATO bypass Ukraine, constructing new railway lines and improving port facilities so that oil and gas can be sent directly to European markets. The plans to end all transits of Russian energy across Ukrainian territory are northern route and a long planned southern route. At the end of 2014, after Moscow was forced to cancel the initial South Stream line due to EU regulations forbidding companies from owning both the gas and pipelines, Russia announced a new "Turkish stream" that would send Russian Energy to Turkey for transshipment to Europe. After the inclusion of Greece in the Turkish stream project, the Russian gas will be transferred to Europe over Turkey and Greece. Turkish stream project which is being built will lead to the loss of Ukraine's status as a key energy transit country and as a buffer zone between Russia and Euro-Atlantic Community (Stang, 2015, pp. 2-3). In June 2015, at the 19th St. Petersburg International Economic Forum, a nonbinding memorandum was signed that commits a European consortium to work with Russia to construct a second pipeline next to existing Nord stream line that traverses the Baltic Sea to directly supply Germany from Russian territory. It is planned to be the shortest route combining the natural gas sites in the north of Russia with the European markets. Thus, Russia's state gas firm OAO Gas prom aims at becoming the main gas supplier of Europe. The biggest attempt of Russia, which had serious problems in the European market, was to turn back to Asia and conclude a natural gas treaty with China. Hence, market losses were recovered. Still, Russia still wants to turn back to its strong relationships with Germany, France and Spain before the Ukraine crisis. The additional two pipelines of Gazprom towards Germany can be evaluated in this sense (Matalucci, 2015). However, the EU decided to extend the economic sanctions which had been put into practice against Russia in July 2014 until January 31, 2016 due to the activities damaging the stability in the east of Ukraine.

Eurasian Economic Union increasingly engages in "normative rivalry" with the EU in the so-called "shared neighborhood" for Russia. EU's dominance over Eurasia and post soviet space was prevented with the formation of a Russia-led regional integration bloc. The most ambitious mechanism for the export of EU 
governance to the post-Soviet countries is the Association Agreement. The so-called Deep and Comprehensive Free Trade Agreement (DCFTA) is an integral part of it. Russia has begun to compete in a domain where the EU has exercised a monopoly. Russia explicitly presents the EEU as an alternative to EU-led economic integration. Besides the competition, the Presidents of Russia and Kazakhstan voiced support for the idea of a deeper economic integration with the EU (the fact that EU has been the largest trading partner of Russia and Kazakhstan) Russian President Vladimir Putin suggested putting a free trade zone with the EU back on the agenda during the EU-Russia Summit on January 28th, 2014. The protypes of potential EU-EEU integration may include a comprehensive economic and trade agreement (CETA). A CETA based integration could have posed an alternative for the new Trans-Atlantic Partnership which the USA wanted to establish with the EU. Although there are discussions on which one is more appropriate for the economic benefits of the union in terms of the EU, the Ukraine crisis and economic sanctions on Russia extended until 2016 prevented such integration ( Pelipas, Tochitskaya, \& Vinokurov, 2014, pp. 9-11; Dragneva \& Wolczuk, 2012).

Europe-USA economic sanctions had significant results for Russia. For the opinions of Alexander Dugin, who supports following a policy isolated from the West for strengthening Russia if required, the Ukraine crisis can be evaluated as an important development. Against the West which started to follow a political and economic isolation policy, Russia got alienated from the Atlanticist foreign policy and oriented to the East. EEU is currently initiating a number of free-trade agreements with many countries such as India, Vietnam, Egypt, and Iran. This helps Russia to break the Western sanctions and isolation. Although the Western sanctions especially had a purpose to change the present power of Putin in Russia, the public support was found for the President Putin by $89 \%$ in the last survey of Levada Center, the Russian independent public vote research establishment. It now seems difficult for the Atlanticists, who see Russia as a part of the western world and support integration into the Western values, to gain strength in the country after the last sanctions and implementations (Simes Jr., 2015). Integration into Europe over the ideal "Common European Home" initiated by Gorbachev until 1993 doesn't seem attractive for the Russian public for the "trust" issue any more. While the countries of the immediate environment and the Eurasian identity enable the consideration of Russia as one of the super powers in the international system, Europe will continue to be seen only as an economic market. Against the isolation which is tried to be formed to take down Russia, important decisions at BRICS such as establishing a common currency and bank, SCO expansion and connection of the Eurasian Economic Union with the Silk Road Zone and setting new rules in the global economy explain the strong support behind the power of the President Putin. It gained a financially strong and reliable partner by directing its embargoed energy and weapon industrial areas to China. Russia, which didn't give up and re-determined a strategy with its self-help system, prevented the Eurasia dominance of the West with the Eurasian Economic Union and the Shanghai Cooperation Organization.

\section{A New Power Balance Within the Global Competition}

Today, the fate of the world economy is set by the performance of the USA, China, Europe and the Emerging market economies. A new transformation period has again started in the economic potential order across the world and the center has tended to shift from the west to the east. BRICS countries, which prevent the extreme decrease in the average growth rate of the world economy and defined as the emerging powers, stated that they wanted to eliminate the "West-East" discrimination, which had been produced by the West in line with the ideological and cultural requirements of its own sovereignty, and to establish a new capitalist 
world order that wasn't based on the domination of the West. Having a better say in the contribution of the financial structure that reflects the Western domination to the administration of the IMF and World Bank forces them for a change leaving dollar and executing transactions with their own currencies in the investments of the New Development Bank of BRICS, which is an alternative to the above stated institutions, and among them (Tiezzi, 2015). Therefore, under the international economic and political conditions in great recession since 2008 financial crisis, decisions on a new bank and common currency made at the Seventh BRICS Summit which was held on June 9-10, 2015 in Ufa have a historical importance in respect of the world economy. China, Russia and Brazil, which experienced the unsuccessful results of the USA based Western economic model in development and their destruction within the country, present an alternative development model to the remaining countries of the world and create attraction power by continuing the opinion of India, which called for an "alternative new order" with Nehru in 1970s.

Alternative power centers of Russia and China, which oppose to the economic and political domination of the world by a single state, are also significant for the emergence of an equalitarian and fair world order in the international system. BRICS and SCO constitute an alternative G8 for Russia which is excluded from G8 due to sanctions. China aims at establishing a new order which is more suitable for its own benefits instead of having stability in the international economic order it didn't establish itself in accordance with the "May Fourth Movement Spirit" that appeared after 1914 (Heath, 2015). It builds a diplomatic-commercial-cultural network with the new silk road project" aiming at establishing intercontinental economic financial network and internationalization of the Chinese money (IMF's consideration of the Chinese money as the reserve money) by making infrastructure investments such as railway, harbor, airport, dam, oil and natural gas pipelines. Mccoy stated that China subdued the domination of the USA on seas by land through its initiation of fast railways, oil and gas pipelines in partnership with Russia in Eurasia on energy and use of the Asian Infrastructure Investment Bank where it has the biggest share in these projects (McCoy, 2015). Whereas a multipolar international order, which Russia strongly defends, provided equality between states, Robert Kaplan, who claims that the relationship between them didn't bring stability, but anarchy with it, asserted that a states order disciplined with the power of a state brought peace and stability despite all the negativities. In line with the view supporting that the center of capitalism must stay at a liberal state, E. H. Carr stated the USA must designate this power again instead of a hegemony shifting from the USA to China (Kaplan, 2013).

The basic characteristic of the hegemonic transition periods is the effort made by the state which holds the control mechanisms of the system to establish new alliances for maintaining its present strong position.USA tries to put extensive free trade and investment agreements into practice which will make the countries depend on them again. The Transatlantic Trade and Investment Partnership (TTIP) Agreement (Gray, 2013) with the EU, which is considered as Economic Nato carries out the negotiations of a Trans-Pacific partnership (Australia, Brunei, Malaysia, Mexico, Japan, Canada, Peru, Singapore, Chile, Vietnam, and New Zealand) including 12 countries and excluding China. If both agreements come into force, $63 \%$ of the global economic earning will be combined in a single market. It is assumed that the USA plans the imposition of the rules of the West-centered world economy's political model by taking Europe and Japan under the name of "Transatlantic Renaissance" (Nuland, 2013). Meanwhile, it is also considered as increasing the competition power of the liberal capitalist bloc against the BRICS countries which prefer a capitalist model where the state has a strong and determinative role in economy and as a geopolitical defiance against China globally and regionally.

World trade which Jagdish Bhagwati (1995) defines as "spaghetti bowl" evolves into a very complicated 
structure. China that has the largest volume of trade at international ranking continues to be considered as a more important trade partner than USA for the other states. Asian countries have put the Regional Comprehensive Economic Partnership (RCEP) Project that includes China into practice by focusing on the multilateral economic relations in response to the efforts of the USA trying to isolate China with the Trans-Pacific Partnership in the Asian region. The Association of South East Asian Nations (ASEAN) includes China, Japan, South Korea, India, Australia and New Zealand along with ten member countries. In addition, they have strengthened their relationships in regional formations in which they include themselves such as China's New Silk Road Project, the Eurasian Economic Union-Russia's effort to found hegemony on its own zone of influence - and the SCO. It is thought that USA's financial power meeting the infrastructural investment needs of the Asian countries has finished with the Asian Infrastructure Investment Bank which constitutes the biggest share of China. Except for the IMF and the World Bank, China has founded a financial network with a fund corresponding to three trillion dollars that it can use at will. Briefly stated, it made the multi-polarity of the international system clear against the western bloc with such foundations as the Silk Road Economic Belt, SCO, ASEAN, Eurasian Economic Union and Asian Infrastructure Investment Bank.

While the negotiations on Trans-Pacific and Trans-Atlantic agreements continue, the discussions which regard that sovereignty will be suspended in the countries that will become members and absolute gain will not be provided for the countries are underway. Moreover, England, France, Germany, Italy, Japan, Australia, New Zealand and South Korea have joined the Asian Infrastructure Investment Bank (29 June signed the articles of agreement by China and 49 countries) as founding members, which is a financial structuring formed by the Chinese initiative seen as the biggest threat by the USA to its hegemony (Hong, 2015). It is also described as a decrease in the power of the USA. While the USA leads to pressure on Russia due to decreasing oil prices, China that imports a majority of its energy has an economic boon. Whereas Russia-China axle constitutes an important balance, they provide an alternative to the World Bank and IMF's power of affecting the developing countries. When the Asian Investment Bank is founded, it will enable the regional sources to stay in the region, but its sources financing economic growth in the West, consumption and state debts will deplete. At this point, the possibility of the foundation of cooperation between the EU and the Eurasian Economic Union is crucial. Thus, it can be said that the shift of the center of the world economy from West to East will have come to a conclusion.

\section{Conclusion}

The global financial crisis, which began in 2008, prompted countries worldwide to search for new ways of minimizing economic risks and achieving sustainable development. This proved a major factor in revitalizing regional integration processes. The collapse of the USSR was the starting point for a multitude of projects aimed at creating a new framework of cooperation among the former Soviet Union (FSU) republics, which had become independent states. The last 20 years has witnessed a significant number of initiatives in the region. The various attempts to reunite the former Soviet Union may also be due to a desire to restore its former strength and area of influence - beginning with the establishment of the CIS, then the various customs unions and treaties and finally the Eurasian Economic Community. The Eurasian Union forms a foundation for the unification of the post-Soviet area in terms of economic and foreign policy. Although all the members of the union are on equal status, Russia is trying to increase in the geopolitical role of the EEU.

Establishing common markets on oil, gas and electricity" which is among the long-term goals is one of the 
factors resulting in the union's gaining importance. But the opinion differences among the member states as in the CIS raise doubts on the continuity of the union. Trade disputes on quality of agricultural goods and efforts to protect their national markets, decrease in the oil prices and sanctions against the Russian economy have had a negative impact on the development of the EEU (Boguslavska, 2015). The members of the union where the incomes obtained from the energy export are the basic leading elements of their economies and which are behind about technological innovation and modernization, must take important steps in terms of structural and institutional transformation.

For the members of the union that are not full-steady economically, there aren't any other regional formations making themselves develop a distinctive economic identity in the world economic system. The SCO and the New Silk Road project led by China or the Eastern Partnership Project started by the USA in 2009 are further regressive alternatives for the members of the union that want to preserve their sovereignty. As Dmitri Trenin (2012) mentioned in the book "The End of Eurasia (2002)", they will change into "disappearing reality". Apart from being countries dependent on China or EU and the USA, a third option is to be included in a union under the security of Russia about economic subjects. As long as Russia that has an effective position in BRICS signs new economic agreements, it also tends to move these opportunities inside the EEU. Meanwhile, Brzezinsky indicates that the domination of this geopolitical region by only one power (China) through the establishment of necessary financial and economic connections will be an undesired situation for the USA within the fight for hegemony. A union controlled by Russia also balances China in the region.

On the other hand, Russia poses a threat to damage the stability along with its provision of security. When the security of the Russian ethnic groups falls into danger as in the example of Ukraine, the decision of military intervention is challenging also for Kazakhstan and Belarus which have these groups in their territories (Russian population living in the North Kazakhstan is 23\%). When western-oriented regimes come into power in these countries, this probability seems always possible. This can be considered as the biggest reason which may cause the union to come to an end. However, Russia tends to risk this integration project that officiates as a bridge between the Asia-Pacific and the Europe and is the new center of economic power as an alternative to the West in its vision of foreign policy which establishes the multipolar international system. It expects Uzbekistan, Turkmenistan and even Mongolia to join as new members in order to expand further. Free trade agreements which are planned to be concluded with more than 40 countries will expand the sphere of influence of the EEU geopolitically. These free trade agreements will enable the union to compete with Trans-Atlantic Trade and Investment Partnership and Trans-Pacific Partnership.

\section{References}

Agnihotri, G. (2015). What would A Saudi-Russian partnership mean for world energy. Oil Price.com. Retrieved June 24, 2015, from http://oilprice.com/Energy/Crude-Oil/What-Would-A-Saudi-Russian-Partnership-Mean-For-World-Energy.html

Balzer, H. (2005). The Putin thesis and Russian energy policy. Post-Soviet Affairs, 21(3), 210-225.

Bhagwati, J. (1995). US trade policy: The infatuation with FTAs Colombia University academic commons. Retrieved from http://hdl.handle.net/10022/AC:P:15619

Boguslavska, K. (2015). The first steps of the Eurasian Economic Union: Disputes, initiatives and results. The International Relations and Security Network. Retrieved August 3, 2015, from http://www.isn.ethz.ch/Digital-Library/Articles/Detail/?lng=en\&id=192642

Brzezinski, Z. (1986). Game plan: A geostrategic framework for the conduct of the US-Soviet contest. Boston: Atlantic Monthly Press.

Dragneva, R., \& Wolczuk, K. (2012). Russia, the Eurasian customs Union and the EU: Cooperation, stagnation or rivalry. 
Chatham House Briefing Paper. Retrieved August 2012, from, http://www.chathamhouse.org/sites/default/files/public/Research/Russia\%20and\%20Eurasia/0812bp_dragnevawolczuk.pdf

Dugin, A. (2003). Russian geopolitics, Eurasians' perspective. İstanbul: Küre Publ.

Escobar, P. (2014). Empire of Chaos the roving eye collection Vol. 1. USA Nimble Books.a

Eurasian Economic Commission. (2013). Eurasian economic integration: Facts and figures. Retrieved from http://eurasiancommission.org/ru/Documents/broshura26Body_ENGL_final2013_2.pdf\#14

Francis, D. (2015). Iran's return to oil markets is good for energy firms but bad for Russia. Foreign Policy. Retrieved July 14 , 2015, from http://foreignpolicy.com/2015/07/14/irans-return-to-oil-markets-is-good-for-energy-firms-but-bad-forrussia/

?utm_content=bufferfa172\&utm_medium=social\&utm_source=facebook.com\&utm_campaign=buffer

Gorenberg, D. (2014). Countering color revolutions: Russia's new security strategy and its implications for US policy. Russian Military Reform.

Gray, B. C. (2013). An economic NATO: A new alliance for a new global order. Atlantic Council, Issue Brief.

Heath, T. (2015). China's emerging vision for world order. The National Interest. Retrieved May 21, 2015, from http://nationalinterest.org/feature/chinas-emerging-vision-world-order-12934?page=3

Hong, Y. (2015). AIIB is seen very differently in the US, Europe and China. The Diplomat. Retrieved May 8, 2015, from http://thediplomat.com/2015/05/the-aiib-is-seen-very-differently-in-the-us-europe-and-china/

Hoyos, C. (2007). The new seven sisters: Oil and gas giants dwarf western rivals. Financial Times. Retrieved March 12, 2007, from http://www.ft.com/cms/s/2/471ae1b8-d001-11db-94cb-000b5df10621.html\#axzz3gbcsLw27

Ianand, B., \& Samuel, C. (2007). The Siloviki in Putin's Russia: Who they are and what they want? The Washington Quaterly, 30(1), 83-92.

International Energy Statistics. (2015). US energy information administration. Retrieved from http://www.eia.gov

Jaffe, M. A. (2007). The changing role of national oil companies in international oil markets. Baker Institute Policy Report No. 35 , Houston Baker Institute.

Kaplan, R. (2013). The world is marching toward anarchy. Real Clear World. Retrieved April 18, 2013, from http://www.realclearworld.com/articles/2013/04/18/the_world_is_marching_toward_anarchy_105085.html

Li, X. (2009). Redefining consensus : Ten economic principles. China Economic Journal, 2(3), 297-311

Lukin, A. (2015). Mackinder revisited: Will China Establish Eurasian Empire 3.0? The Diplomat. Retrieved February 7, 2015, from http://www.thediplomat.com

Mackinder, H. J. (1904). The geographical pivot of history. Geographical Journal, XXIII, 421-444.

Malcolm, N., Pravda, A., Allison, R., \& Light, M. (1996). Internal factors in Russian foreign policy. Oxford: Oxford University Press.

Matalucci, S. (2015). Gasprom signs deals with E. On, OMW, shell for new pipeline to Germany. Natural Gas Europe. Retrieved from June 18, 2015, from http://www.naturalgaseurope.com/gazprom-signs-deals-with-e.on-omv-shell-for-new-pipe-to-germany-24262

Mccoy, A. (2015). The Geopolitics of American global decline, Washington Versus China in the twenty first Century. Tom $\begin{array}{lllll}\text { dispatch. } & \text { Retrieved } & \text { June } & \text { from }\end{array}$ http://www.tomdispatch.com/post/176007/tomgram\%3A_alfred_mccoy,_washington's_great_game_and_why_it's_failing_/

Murrel, P. (1993). What is shock therapy ? What did it do in Poland and Russia. Post Soviet Affairs, 9(2), 111-140.

Nartov, N. A. , \& Nartov, V. N (2007). Geopolitika (4th ed.). Edinstvo, Moskva.

Nuland, V. ( 2013). Toward a transatlantic Renaissence: Ensuring our shared future. US Department of State. Retrieved November 13, 2013, from http://www.state.gov/p/eur/rls/rm/2013/nov/217560.htm

Pannier, B. (2008). Russia, Iran and Qatar consider gas Troika-or gas Cartel. Payv and Iran News. Retrieved October 23, 2008, from http://payvand.com/news/08/oct/1236.html

Pelipas, I., Tochitskaya, I., \& Vinokurov, E. (2014). Quantifying Economic Integration of the European Union and the Eurasian Economic Union : Metholodological approaches. Eurasian Development Bank, Report 23.

Pomfret, R. (1995). The Economies of Central Asia. New Jersey : Princeton Legacy Library.

President of Russia. (2015). Reception on behalf of the Russian President in honor of the BRICS and SCO leaders. Retrieved July 9, 2015, from http://en.kremlin.ru/events/president/news/49904

Putin, V. (2011). A new integration project for Eurasia: The future in making. Izvestia. Retrieved October 3, 2011, from http://www.russianmission.eu/en/news/article-prime-minister-vladimir-putin-new-integration-project-eurasia-future-making-i zvestia-3- 
Renz, B. (2006). Putin's militocracy? An alternative interpretation of Siloviki in contemporary Russian Politics. Europe-Asian Studies, 58(6), 903-924.

RT. (2015). Empire Chaos' in the house. Retrieved January 27, 2015, http://www.rt.com/op-edge/226719-empire-saudi-usa-king-obama/

Simes Jr, D. (2015). 5 things you need to know about Putin's popularity in Russia. The National Interest. Retrieved July 21, 2015, from http://nationalinterest.org/feature/5-things-you-need-know-about-putins-popularity-russia-13380

Spiegel. (2005). Embassy espionage: The NSA's secret spy hub in Berlin. Spiegel International Online. Retrieved October 27, 2013, from http://www.spiegel.de/international/germany/cover-story-how-nsa-spied-on-merkel-cell-phone-from-berlin -embassy-a-930205.html

Stang, G. (2015). The bear and the beaver: Russia and European energy security. European Union Institute for Security Studies, Brief Issue, July 2015.

Stroev, E., Bliakhman, L., \& Krotov, M. (1999). Russia and Eurasia at the crossroads. London, Springer Verlag.

Tiezzi, S. (2015). Don't forget about the new BRICS bank. The Diplomat. Retrieved July 22, 2015, from, http://thediplomat.com/2015/07/dont-forget-about-the-new-brics-bank/

Trenin, D. (2012). The end of Eurasia: Russia on the border between geopolitics and globalization. Moscow: Carnegie Moscow Center. 